\title{
Application of Remote Sensing, GIS and Hydrogeophysics to Groundwater Exploration in parts of Lagos Metropolis: A case study of Oshodi/Isolo LGA
}

\author{
Epuh, E.E. ${ }^{1}$, Sanni, K.A. ${ }^{2} *$ and Orji, M.J. ${ }^{3}$ \\ ${ }^{1,2 \& 3}$ Department of Surveying and Geoinformatics, University of Lagos, Nigeria \\ Corresponding Author: *sannikhafilah@gmail.com
}

\begin{abstract}
Productivity through groundwater is quite high as compared to surface water, but groundwater resources have not yet been properly exploited. The present study is used to delineate various groundwater potential zones for the assessment of groundwater availability in Lagos metropolis using remote sensing and GIS and hydrogeophysics techniques. Landsat 8, SRTM, geological, soil, and rainfall data were used in the study to prepare various thematic maps, viz., geomorphological, slope, soil, lineament density, rainfall and land use maps. On the basis of relative contribution of each of these maps towards groundwater potential, the weight of each thematic map have been selected and assigned to each map. Hydrogeophysics investigation using Vertical Electric Sounding (VES) was applied to validate the remote sensing and GIS results. All the thematic maps have been registered with one another through ground control points and integrated using the weighted overlay method in GIS for computing groundwater potential index. Based on the methological approach, the ground water potential zones were delineated. The results showed that there are five categories of groundwater potential zones within the study area in which percentage values were contained in each of the categories thereby making major portion of the study area "high" and "moderate" prospect while a few scattered areas have "low" prospect. The very high potential areas are mainly concentrated along the River Alluvium while the "very low" prospect are majorly where there is sand and clay. The best groundwater potential zone is in the southern part due to the presence of fractures, swamp soils which have high infiltration ability and the presence of waterbody which is chiefly accountable for the groundwater recharge in any area. The VES data showed the depth of the aquifer for good water and the polluted aquifer within the study area.
\end{abstract}

Keywords: Remote Sensing, GIS, Hydrogeophysics, Groundwater, Aquifer

\subsection{Introduction}

Water, composed of both surface and groundwater is one of the most significant natural resources which support both human needs and economic development (Ogunba, 2016). As a result of the increasing population and the demand for good quality water to meet the growing needs; such as the agricultural, industrial and domestic uses, quite a lot of attention has been placed on surface water being a component of the hydrological cycle for water supply, particularly in urban areas, while groundwater was considered only as a means of rural water supply. However, the situation is changing even on a global scale (Soladoye and Ajibade, 2014). According to Gronwall et al., (2010), an estimated 269 million urban dwellers depend on well water as their principal source of drinking water. In urban Nigeria, it is estimated that almost 60 percent of the population rely on local water wells. This rapid development of groundwater resources seems to be partly due to large-scale pollution of surface water. The people's need for self-supply of water is due to lack of alternate water sources and the generality with the wide availability of groundwater leading to its low capital development, cost and excellent natural quality (Foster and Chilton, 1993). However, these speedy 
and uncontrollable uses poses many problems as it can lead to over-exploitation if not properly sited and managed.

Groundwater often referred to as a hidden resource, is usually stored between pores in the rock, or in fractures, known as aquifers. Its occurrence, movement and availability in any terrain is largely controlled by the prevalence and orientation of primary and secondary porosity (Solomon, 2003) and permeability of the surface and underlying lithology (Shahid et al., 2000). Though, to determine the location of aquifer, quality of groundwater, physical characteristics of aquifers, etc., in any basin, test drilling and stratigraphy analysis are the most reliable and standard methods. However, such an approach for groundwater investigations is very expensive, time-consuming and requires skilled manpower (Sander et al., 1996). Hence, the application of indirect Remote Sensing method with its advantages of spatial, spectral and temporal availability of data covering large and inaccessible areas within a short time, has emerged as a very useful tool for the assessment, monitoring and management of groundwater resources. Jha et al. (2007); Saraf and Chowdhary (1998); Khan and Moharana (2002) and Sankar (2002) have demonstrated the technique of integration of remote sensing data and GIS tool to be extremely useful for groundwater studies. Consequently, various attempts have been made in the generation of different thematic maps for the delineation of groundwater potential zones in different parts of the country (ObiReddy et al., 2000). The analysis of remotely sensed data along with soil, rainfall, slope, geological map as well as other collateral information with necessary ground checks, helps in generating the base-line information for ground water prospecting. In the present study, a part of Lagos state metropolis has been selected for qualitative evaluation and assessment of ground water potential zones using remotely sensed data, hydrogeophysics and GIS.

\subsection{Methodology}

\subsection{Hydrogeology of the study area}

Lagos state is basically a sedimentary area located within the western part of Nigeria, a zone of coastal creek and lagoon (Figure 1). The area is also developed by barrier beaches associated with sand deposition (Hill and Webb, 1987). The sub-surface geology reveals two basic lithologies; clay and sand deposits. These deposits may be interbedded in places with vegetable remains and peak. The water bearing strata of Lagos state consists of sand, gravel or admixtures from fine through medium to coarse sand and gravel (Longe et al., 1987). Basically, there are four major aquiferous units that are being tapped for the purpose of water supply in the Lagos metropolis. The first aquifer extends from ground level to roughly $12 \mathrm{~m}$ below ground. It consists of alternation layers of clay and sand. This upper aquifer is prone to contamination because of its limited depth.

The second aquifer is encountered between 20 and $100 \mathrm{~m}$ below sea level and it can be found around Ikeja and Ojota axis. This aquifer is of greater importance for water supply purposes throughout Lagos metropolis (Jones and Hockey, 1964). The third aquifer in the central part of Lagos has a depth ranging from 130-160 m below the sea level and the fourth aquifer is located at an elevation of approximately $450 \mathrm{~m}$ below sea level. It is separated from the third aquifer by a rather thick layer of shale of the Ewekoro formation (Jones and Hockey, 1964).

\subsection{Generation of thematic maps}

This basically entails the process of image classification. Table 1 shows the datasets and their sources. On the basis of relative contribution of each of these maps towards groundwater potential, the weight of each thematic map has been selected and assigned to each map as shown in Table 2. In this research, the following steps were put into consideration:

i. Processing of digital images using the various processing techniques, viz; enhancement, filtering, classification and other GIS processes. The image processing was carried out in the spatial reference system of the data source.

ii. Analysis and interpretation of the downloaded satellite data, in order to produce thematic maps, such as lineament density, land-use maps etc

iii. Satellite images which had been geometrically corrected and rectified to the WGS 84 ellipsoid and Universal Transverse Mercator (UTM) projection system were 
downloaded in the GeoTiff image format with its image parameters described in Table 3 .

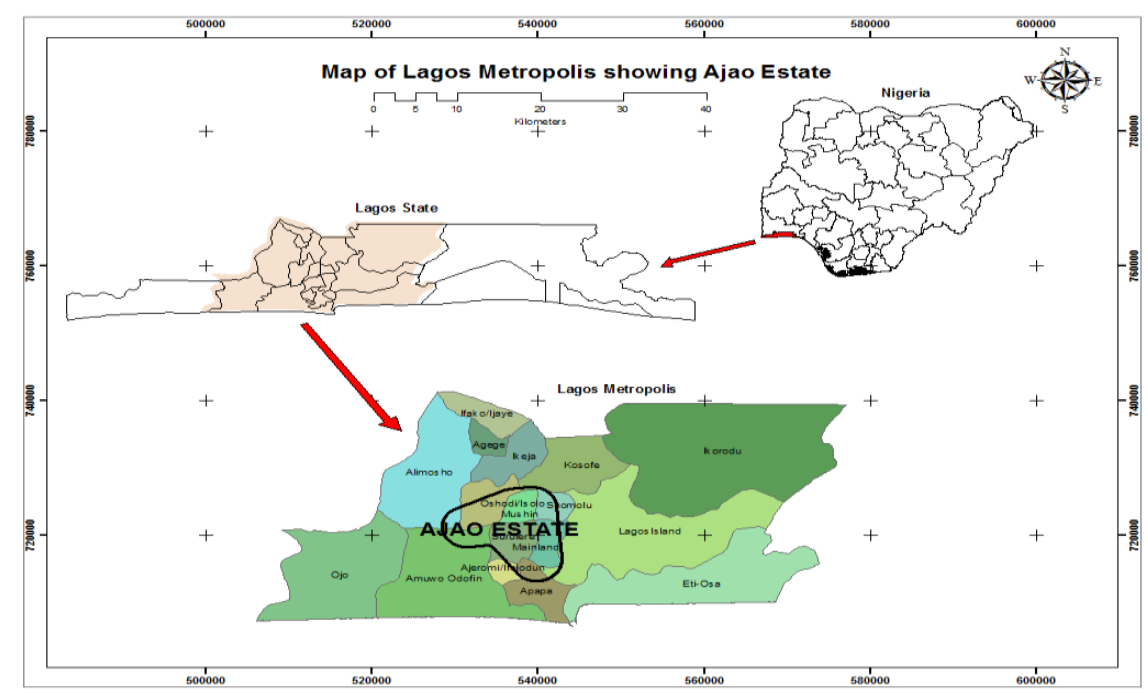

Figure 1: Lagos Metropolis Map

Table 1: Datasets used

\begin{tabular}{|l|l|l|}
\hline Date & Publisher/source & Year \\
\hline Lithology & Primary field data acquired using VES Method & 2018 \\
\hline Landsat Imageries (path191/ row 55) & Downloaded from USGS https://earthexplorer.usgs.gov/ & 2016 \\
\hline Rainfall data & Nigerian Meteorological Agency (NIMET) Annual Report & 2016 \\
\hline SRTM(DEM) (191/55) & Downloaded from https://earthexplorer.usgs.gov/ & 2018 \\
\hline Geological map & Published by Nigeria Geological Survey Agency (NGSA) & 2004 \\
\hline Soil map & $\begin{array}{l}\text { Published by Soil Survey Division, Fed. Dept. of Agric. Land } \\
\text { Resources (FDALR) }\end{array}$ & 1990 \\
\hline
\end{tabular}

Table 2: The assigned weights and scores to different themes and features respectively

\begin{tabular}{|c|c|c|c|c|}
\hline $\mathrm{S} / \mathrm{N}$ & Themes & $\begin{array}{l}\text { Weightage Influence } \\
(\%)\end{array}$ & $\begin{array}{l}\text { Each Class Of Themes } \\
\text { (Features) }\end{array}$ & Score \\
\hline \multirow[t]{3}{*}{1} & \multirow{3}{*}{ Geomorphology } & \multirow[t]{3}{*}{30} & River Alluvium & 10 \\
\hline & & & Amphibole, schist & 8 \\
\hline & & & Sand and clay & 6 \\
\hline \multirow[t]{5}{*}{2} & \multirow[t]{5}{*}{ Rainfall } & \multirow[t]{5}{*}{22} & $1387-1554$ & 10 \\
\hline & & & $1554-1661$ & 20 \\
\hline & & & $1661-1715$ & 30 \\
\hline & & & $1715-1742$ & 40 \\
\hline & & & $1742-1780$ & 50 \\
\hline \multirow[t]{2}{*}{3} & \multirow[t]{2}{*}{ Soil Map } & \multirow[t]{2}{*}{18} & Swamp soils & 40 \\
\hline & & & Reddish Friable Porous Sand & 24 \\
\hline \multirow[t]{3}{*}{4} & \multirow{3}{*}{$\begin{array}{l}\text { Lineament } \\
\text { Density map }\end{array}$} & \multirow[t]{3}{*}{15} & $0-1$ & 9 \\
\hline & & & $2-4$ & 18 \\
\hline & & & $5-7$ & 24 \\
\hline \multirow[t]{5}{*}{5} & \multirow{5}{*}{ Slope } & \multirow[t]{5}{*}{10} & $0-2$ & 40 \\
\hline & & & $2-5$ & 32 \\
\hline & & & $5-10$ & 24 \\
\hline & & & $10-17$ & 16 \\
\hline & & & $17-67$ & 8 \\
\hline \multirow[t]{5}{*}{6} & \multirow[t]{5}{*}{ Land use } & \multirow[t]{5}{*}{5} & WaterBody & 10 \\
\hline & & & Built-up & 8 \\
\hline & & & Wetlands & 6 \\
\hline & & & Vegetation & 4 \\
\hline & & & Barelands & 2 \\
\hline
\end{tabular}


Table 3: The coordinate system

\begin{tabular}{|l|l|}
\hline Parameters & Quantity Value \\
\hline Projection & UTM Zone 31N \\
\hline False easting & 500000.0 \\
\hline False northing & 0.0 \\
\hline Central meridian & 3.0 \\
\hline Scale factor & 0.9996 \\
\hline Latitude of origin & 0.0 \\
\hline Linear Unit & Meter \\
\hline Datum & WGS 1984 \\
\hline
\end{tabular}

\subsection{Methods}

The Landsat satellite image, path and row 191/55 was used. Figure 2 shows the flow chart for the project execution.

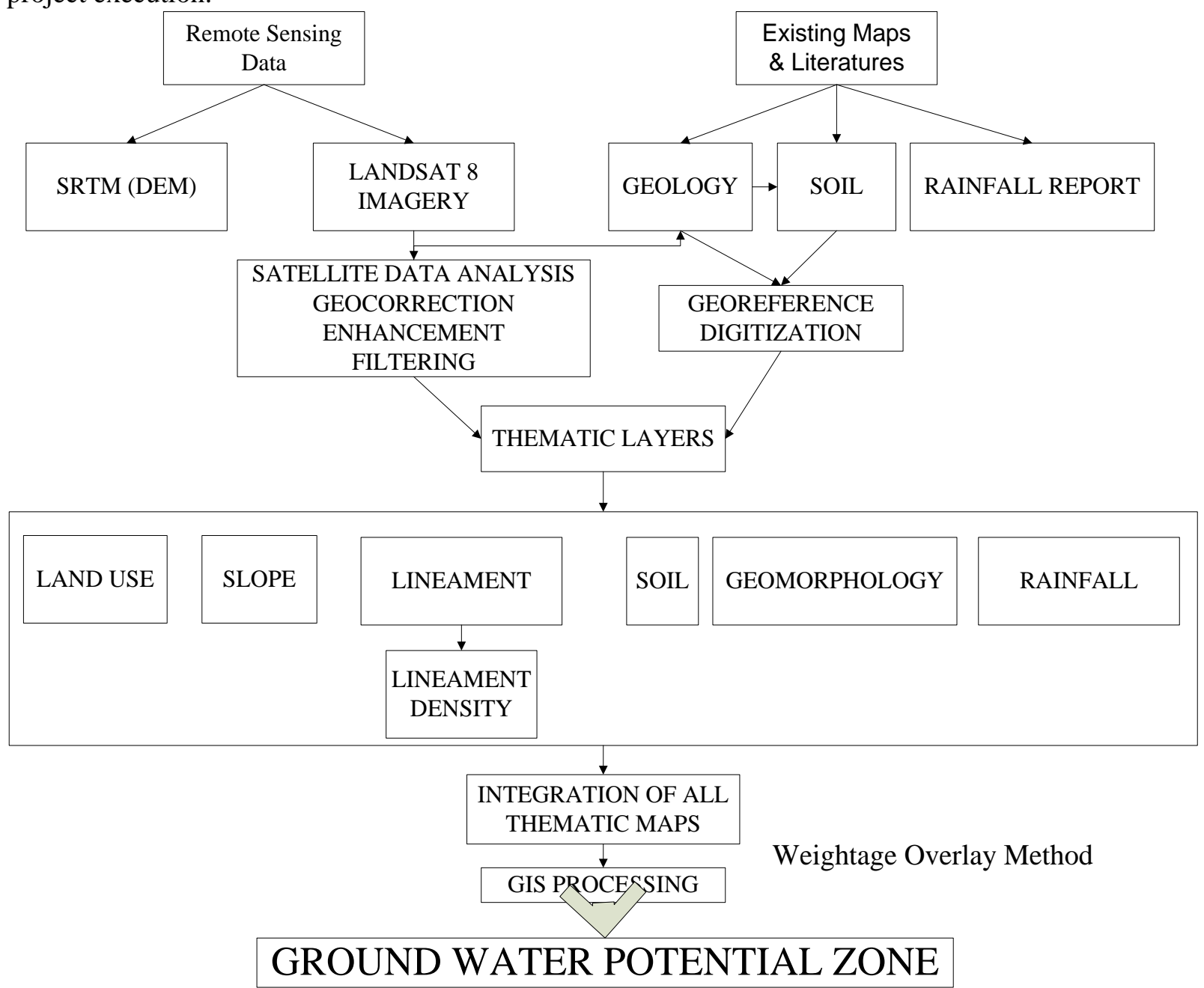

Figure 2: Flowchart for execution

\subsection{Results and Discussion}

\subsection{Results}

This presents the result and analysis of the different thematic maps produced namely: slope, land use/ land cover, geomorphology, lineament density, rainfall and soil map.

\subsubsection{Geomorphology map}

The thematic layer reveals three types of geomorphology units namely; sand and clay, River Alluvium and Amphibole, schist. Larger part of the study area was covered by River alluvium with an area of $2650.25 \mathrm{~km}^{2}$, Amphibole and schist with an area of $1003 \mathrm{~km}^{2}$. The least area was covered under sand and clay which covers an area of $232 \mathrm{~km}^{2}$. Suitable weightage and score has been assigned based on 
the rock influence on groundwater. Thus, for this study, River alluvium is the predominant and most assigned geomorphology unit due to its greater influence on groundwater. Figure 3 shows the Geomorphology map of Lagos metropolis.

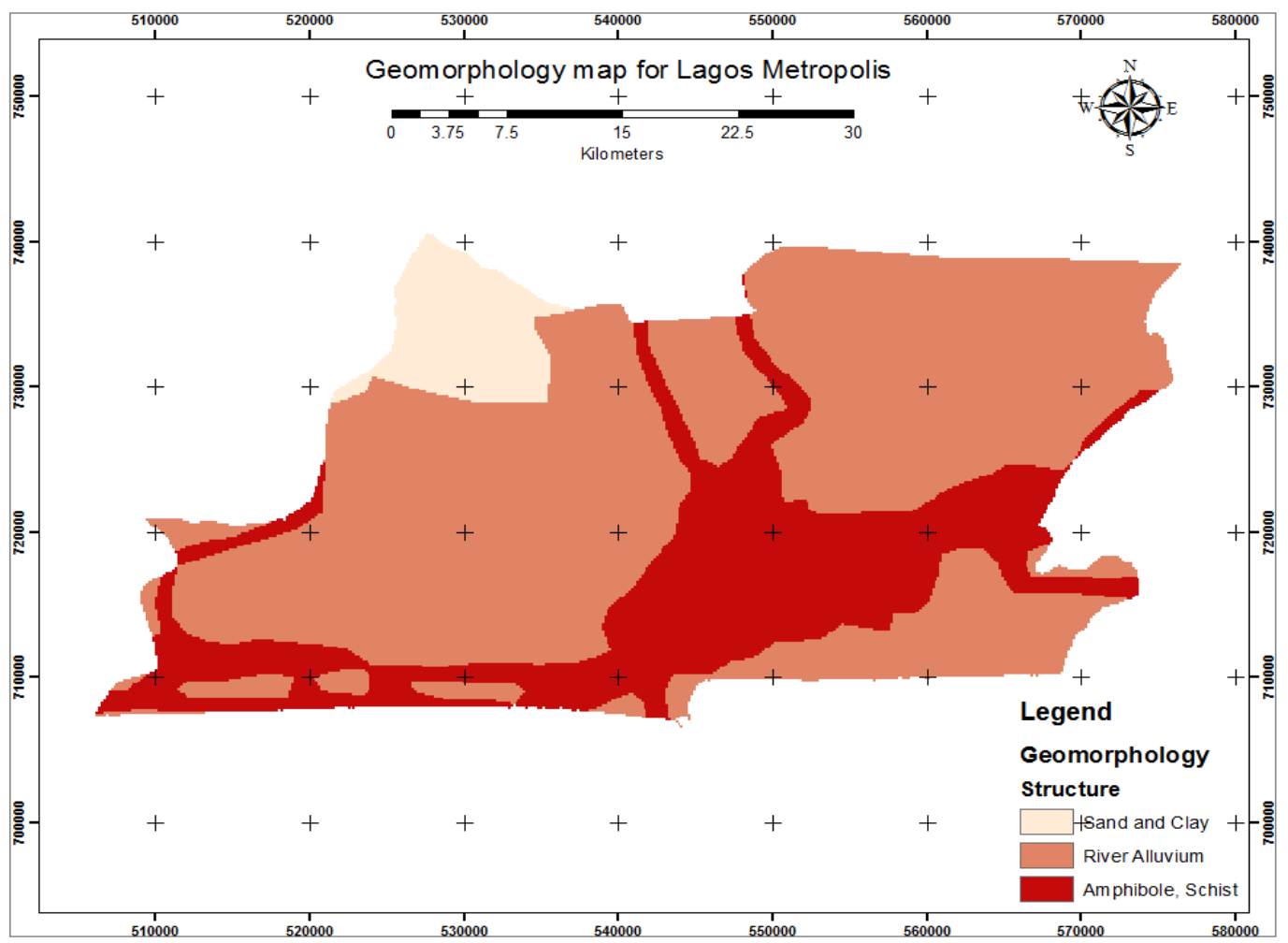

Figure 3: The geomorphology map of Lagos metropolis

\subsubsection{Rainfall map}

Once the spatial distribution of rainfall has been found; the study area were classified into five zones based on the equal interval and suitable weightage which has been assigned for each classes. Figure 4 shows Lagos metropolis rainfall map.

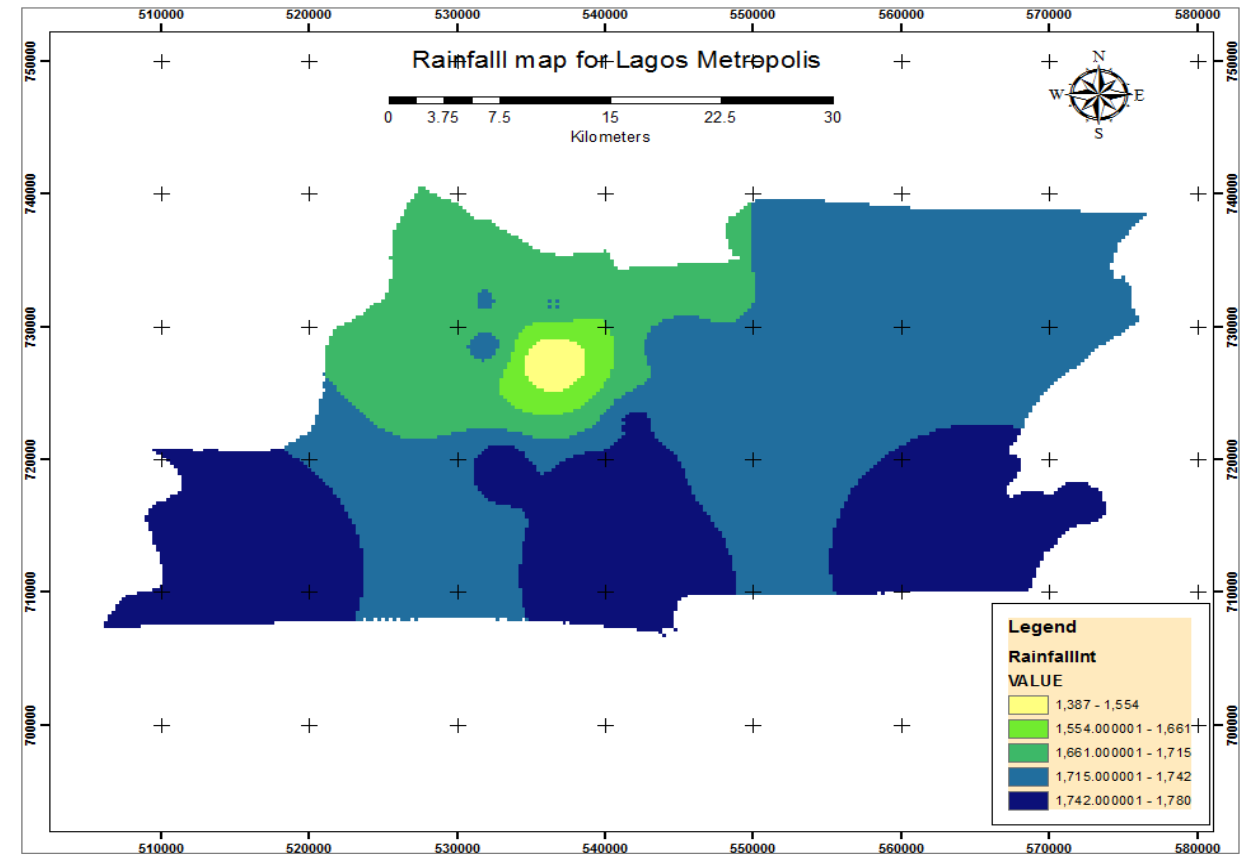

Figure 4: Thematic rainfall map of Lagos metropolis 


\subsubsection{Soil map}

The soil map result (Figure 5), shows that there are two types of soil in our study area which are swamp soils; that covers the southern part of the study area and reddish friable porous sandy clay; covers northern part of the study area. The movement and infiltration of water in these types of soils is not the same. Therefore, based on this property; the score value assigned to swamp soils is greater as they are forested wetlands that may contain water for the whole year.

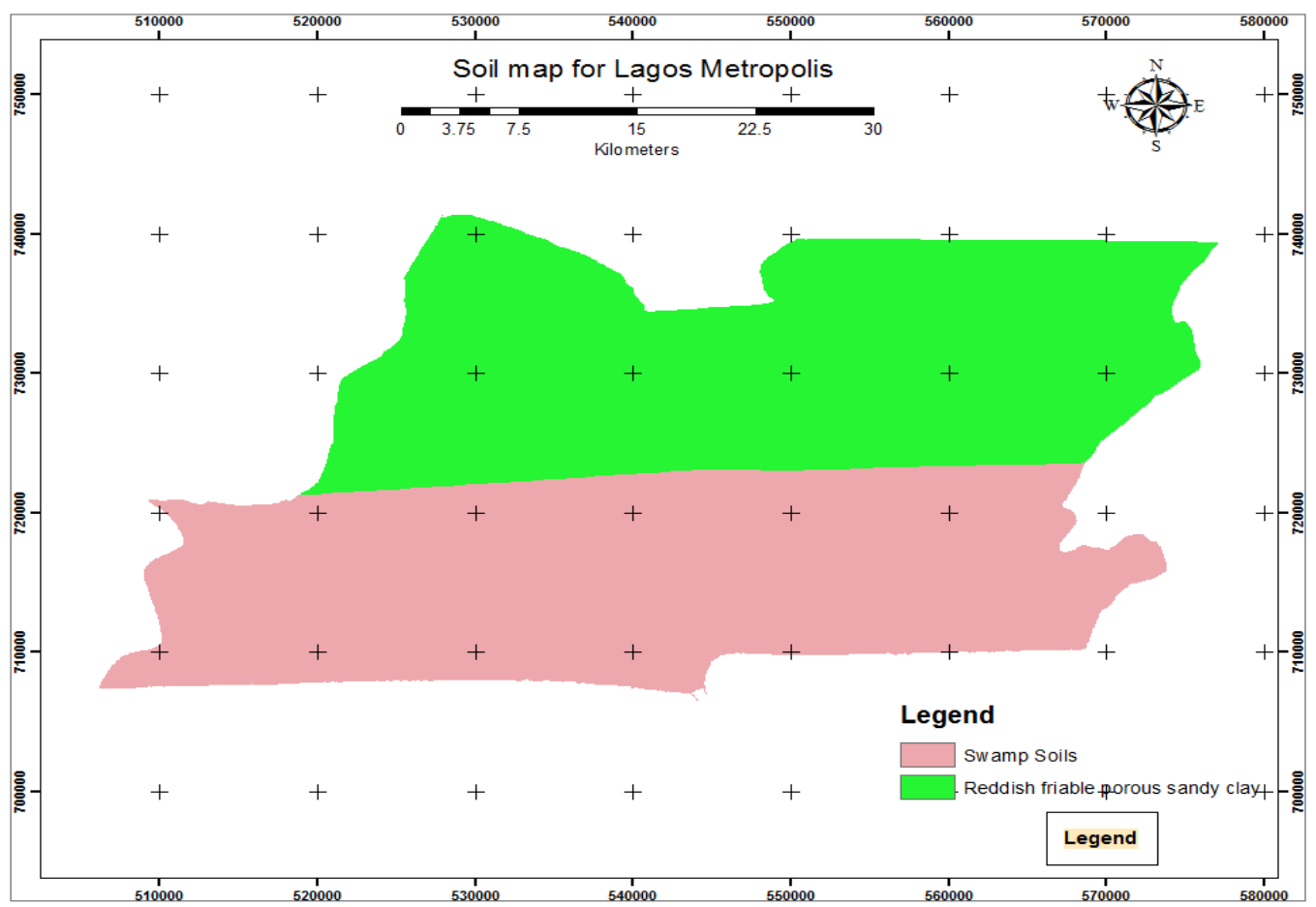

Figure 5: Thematic soil map of Lagos metropolis

\subsubsection{Lineament density map}

The lineament map was prepared from the band 8 pan shapen enhanced imagery. This was done using automated extraction techniques with the aid of PCI Geomatica 2017 Software, It involves transforming each of the shape points into a straight line in parameter space. Arc GIS v. 10.4 was also used for result analysis. Lineament act as a conduit for groundwater flow and hence, are hydrogeologically significant. The values given for lineaments were based primarily on the relation of well yields to proximity of lineaments. Figure 6 show the lineament density result generated after lineament process. Four (4) classes were defined based on distance from the lineament. From the result, values assigned to the various classes in the lineament decreases as the distance of the buffer zones around the lineament increases. This implies that, the closer the buffer zones are to the lineament. The better are the chances of ground water targeting.

\subsubsection{Slope map}

The slope of the study area has been calculated in percentage (\%) based on the Digital Elevation Model (DEM) which was based on the SRTM data. The slope have been classified into five categories varying from 0-67\% as shown in Figure 7. 


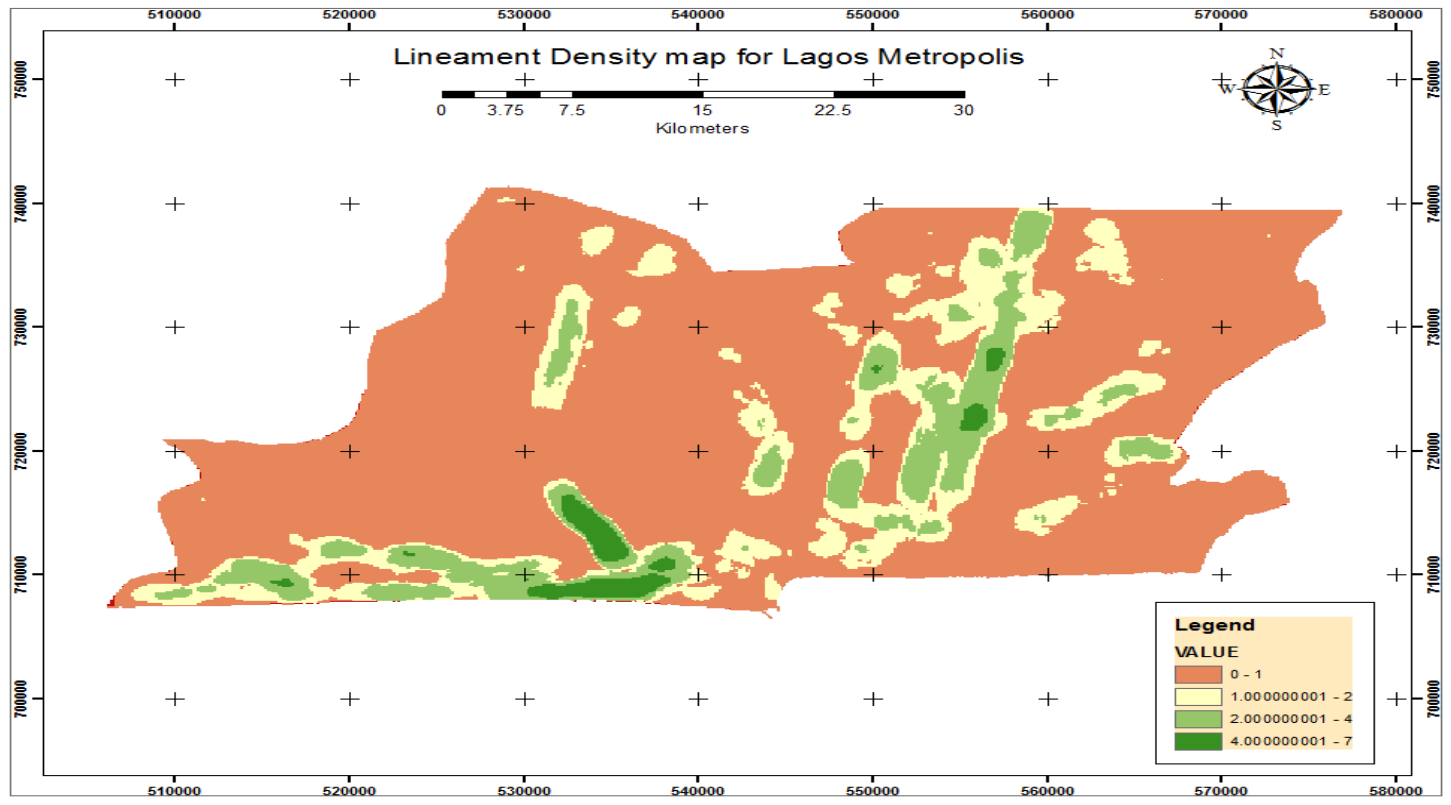

Figure 6: Lineament density map of Lagos metropolis

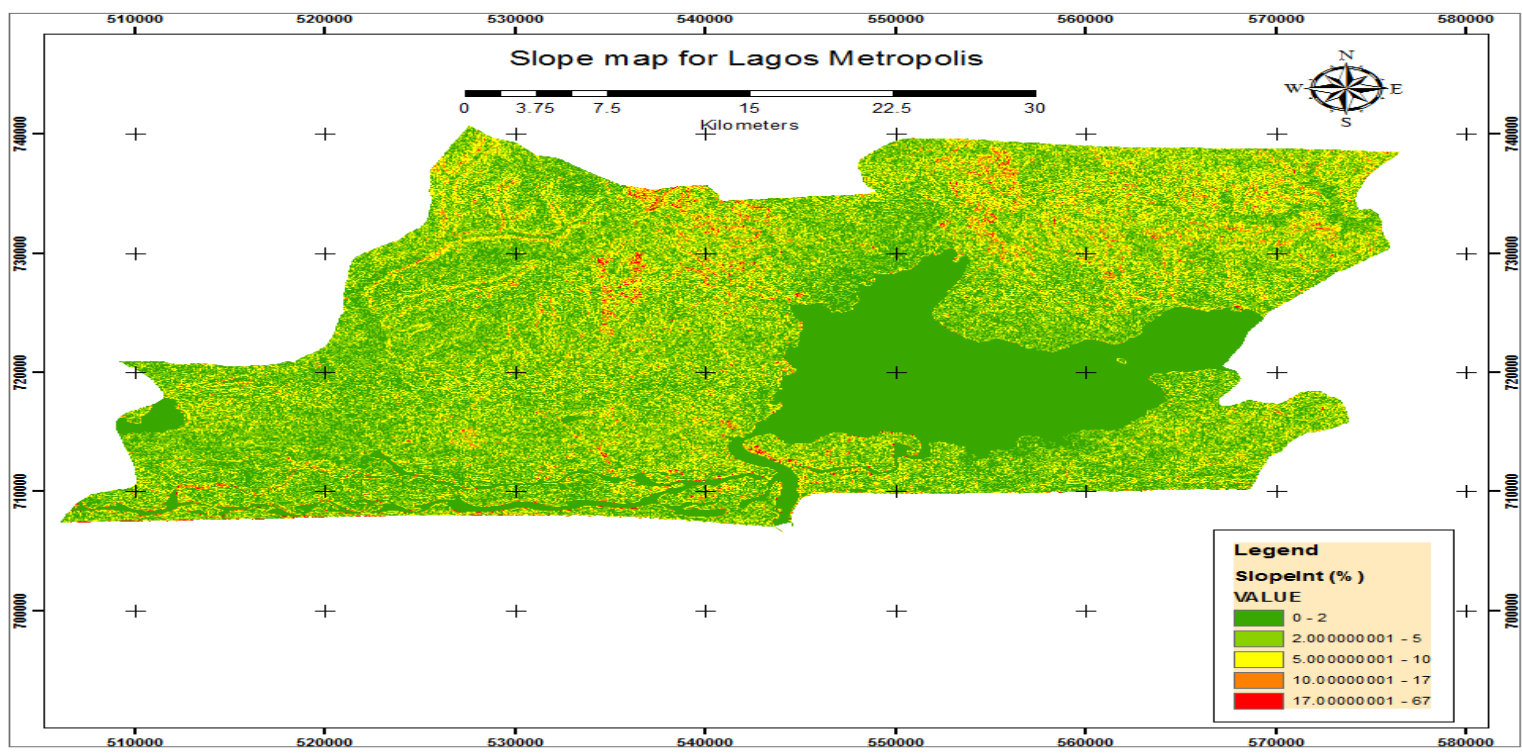

Figure 7: Thematic slope map of Lagos metropolis

3.1.6. Land use / Land cover (LULC) map

The LULC study is useful in assessing impacts of different land uses on water infiltration capacity. From this research, the land use/land cover classification result show that the study area, Lagos metropolis is covered by five classes namely; built-up, bareland, vegetation, wetland and waterbody as shown in Figure 8. It also shows that barely do we have bareland, the entire area is dominated mostly by built-up and waterbody. This dominance help stabilize the surface temperature of the environment, provide clean water and act as shoreline and storm protection. 


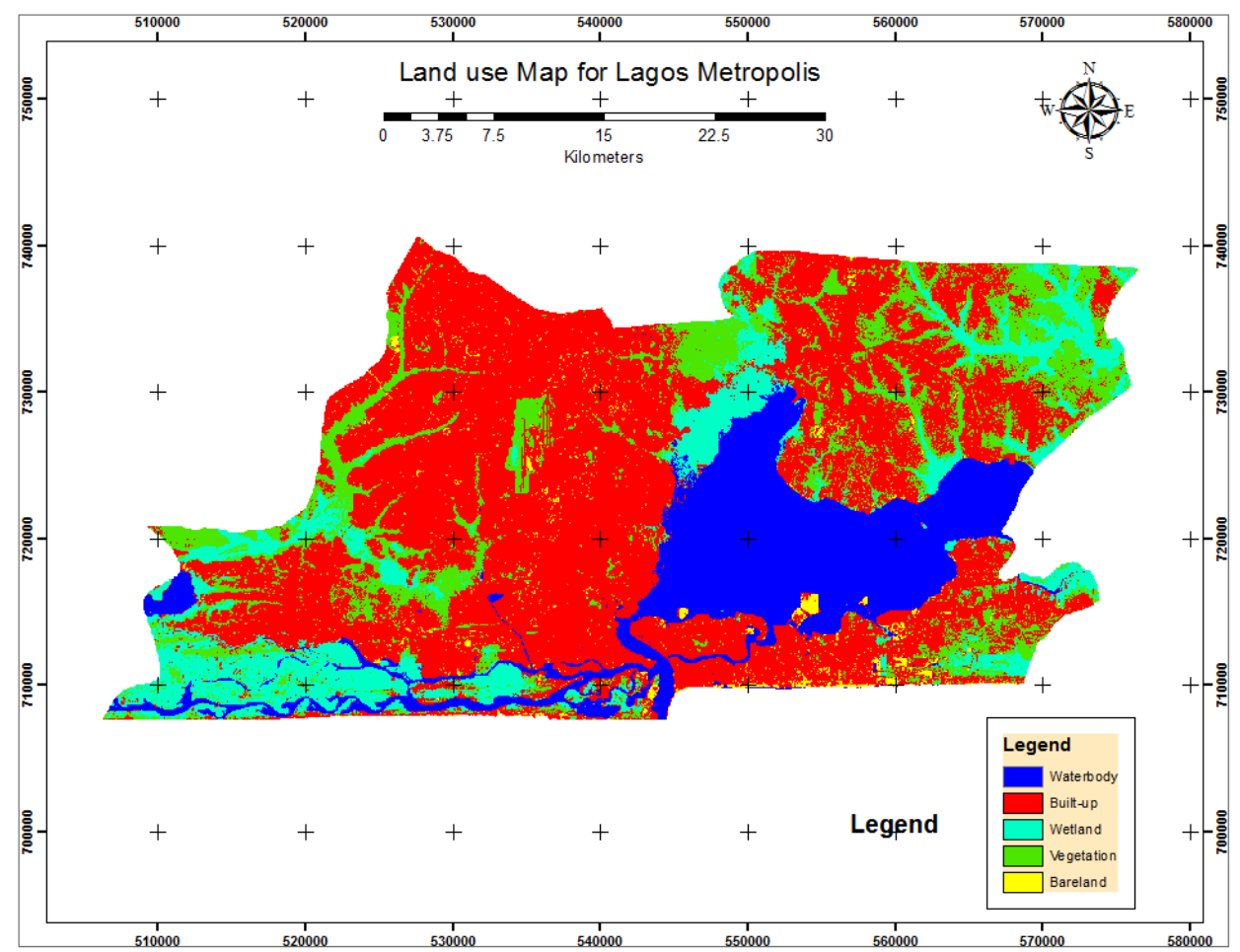

Figure 8: Land use map of Lagos metropolis

3.1.7. Integration of thematic layers using ArcGIS (weightage overlay method)

The ground water potential zones were obtained by overlaying all the six thematic maps in terms of weighted overlay method using the spatial analysis tool in Arc GIS 10.4. Table 2 shows the scores that have been given for each individual parameter of the thematic maps and the weight assigned according to each individual parameter influence on ground water. The weights and rank have been taken, considering the works carried out by researchers such as (Krishnamurthy et al., 1996; Saraf and Chowdhary, 1998). All the thematic maps were converted into raster format and superimposed by weighted overlay method (rank and weight wise thematic maps were integrated with one another through GIS ArcInfo grid environment). For assigning the weight, the geomorphology and rainfall map were assigned higher weight due to their high water infiltration, whereas the slope and land use/land cover were assigned lower weight. After assigning weights to different parameters, as shown in Table 2, individual ranks are given for sub-variable. Then, each of the individual themes were overlaid one at a time to get the final composite map such that each polygon in the final composite map is associated with a particular set of information of all thematic layers. Also, the evaluation of ground water prospect for each polygon in the output is based on the added values of scores of various themes as described in Equation 1.

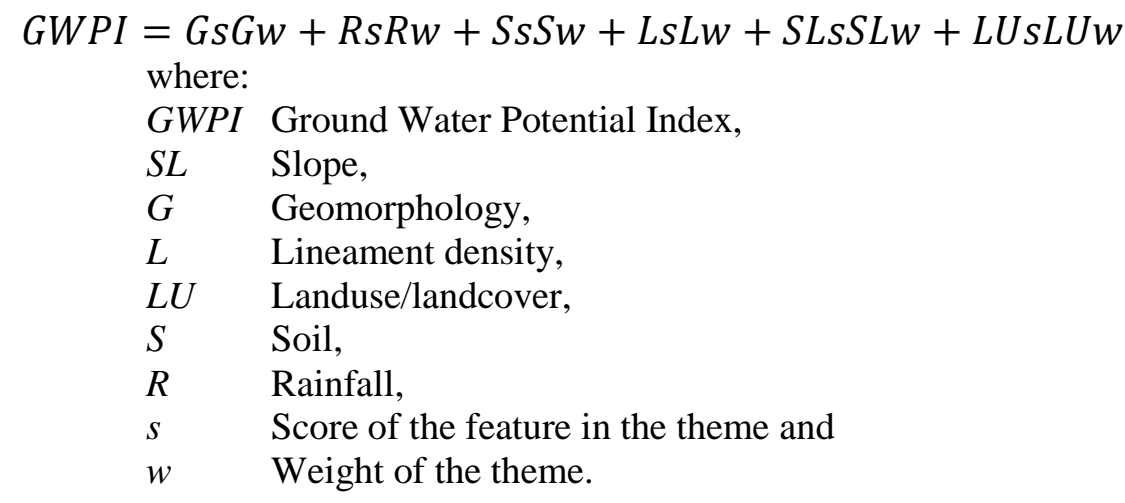

The range of GWPI values (score value) were divided into five classes (called zones) and the GWPI of different polygons falling under different range were grouped into one class. Thus, the entire study 
area was qualitatively divided into five ground water potential zones namely; very high potential, high potential, moderate, low potential and very low potential for groundwater as shown in the Figure 9.

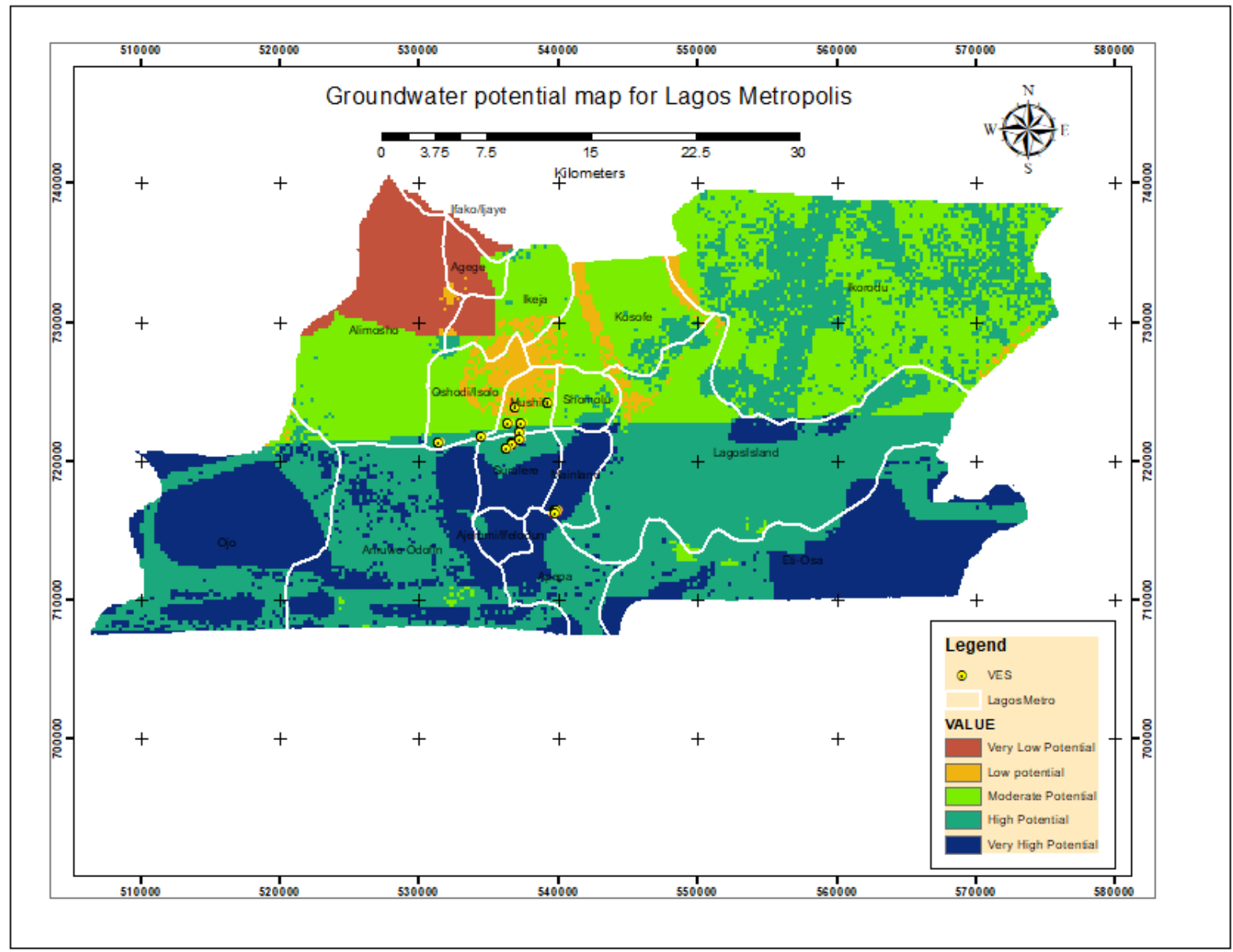

Figure 9: Groundwater potential map for Lagos metropolis

\subsection{Discussion}

The ground water potential zones map given in Figure 9 shows that $22.8 \%$ of the total study area that is Lagos metropolis is under very high zone, $40.4 \%$ of the area falls under high, $28 \%$ of moderate, and $3 \%$ low and 6\% very low potential zone as shown in Table 4 with Figure 10 showing the chart of the distribution. Major portions of the study area has "high" prospect while a few scattered areas have "low" prospect as shown in Figure 10. The very high potential areas are mainly concentrated along the River Alluvium while the "very low" prospect is majorly where there is sand and clay.

Table 4: Area distribution of ground water potential zone

\begin{tabular}{|l|l|l|l|}
\hline S/N & Groundwater potentialzone & Area $(\mathrm{Sq} . \mathrm{Km})$ & Area (Percent) \\
\hline 1 & Very Low & 88.9375 & 5.672486646 \\
\hline 2 & Low & 49.4375 & 3.153153153 \\
\hline 3 & Moderate & 440 & 28.06346169 \\
\hline 4 & High & 632.75 & 40.35717133 \\
\hline 5 & Very High & 356.75 & 22.75372718 \\
\hline & Total & 1567.875 & 100 \\
\hline
\end{tabular}




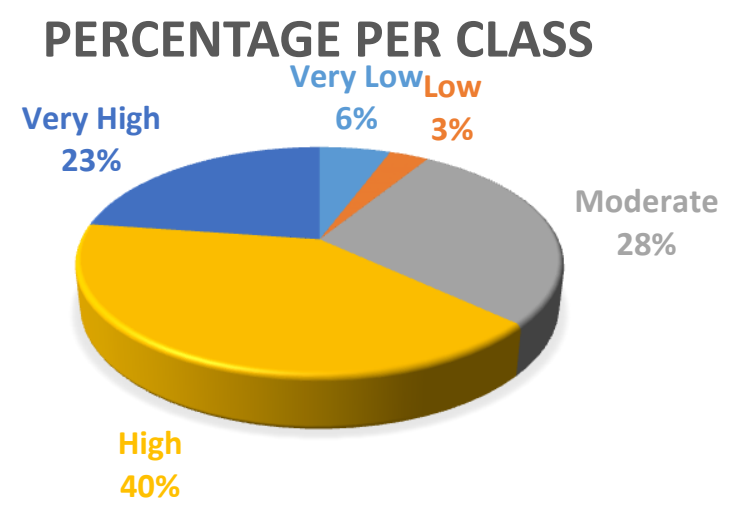

Figure 10: Pie chart showing the area distribution of ground water potential zone

3.2.1. Queries carried out in the project

\section{- Query one}

"DEPTH_M_"

This was carried out to show the VES station that their depth falls between 3 and $10 \mathrm{~m}$ as shown in Figure 11 below.

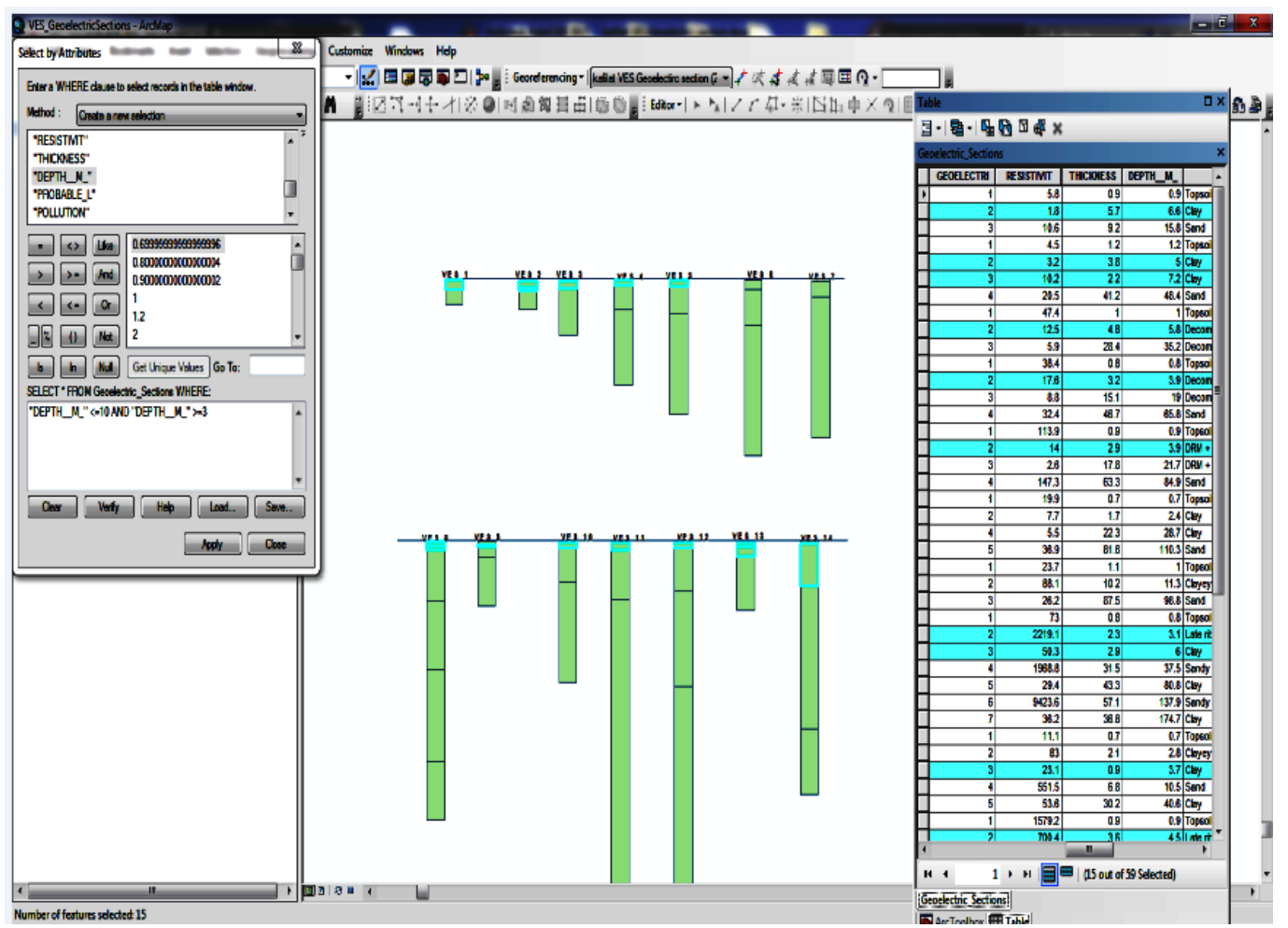

Figure 11: Borehole depths between 3 and $10 \mathrm{~m}$

\section{- Query two}

"POLLUTION"= 'Polluted'. This is done to know areas that are polluted so that one will not bother to drill such areas. From the result, as shown in Figure 12, we found out that VES location 1, 2, 4, 6, 12 falls into that category. 


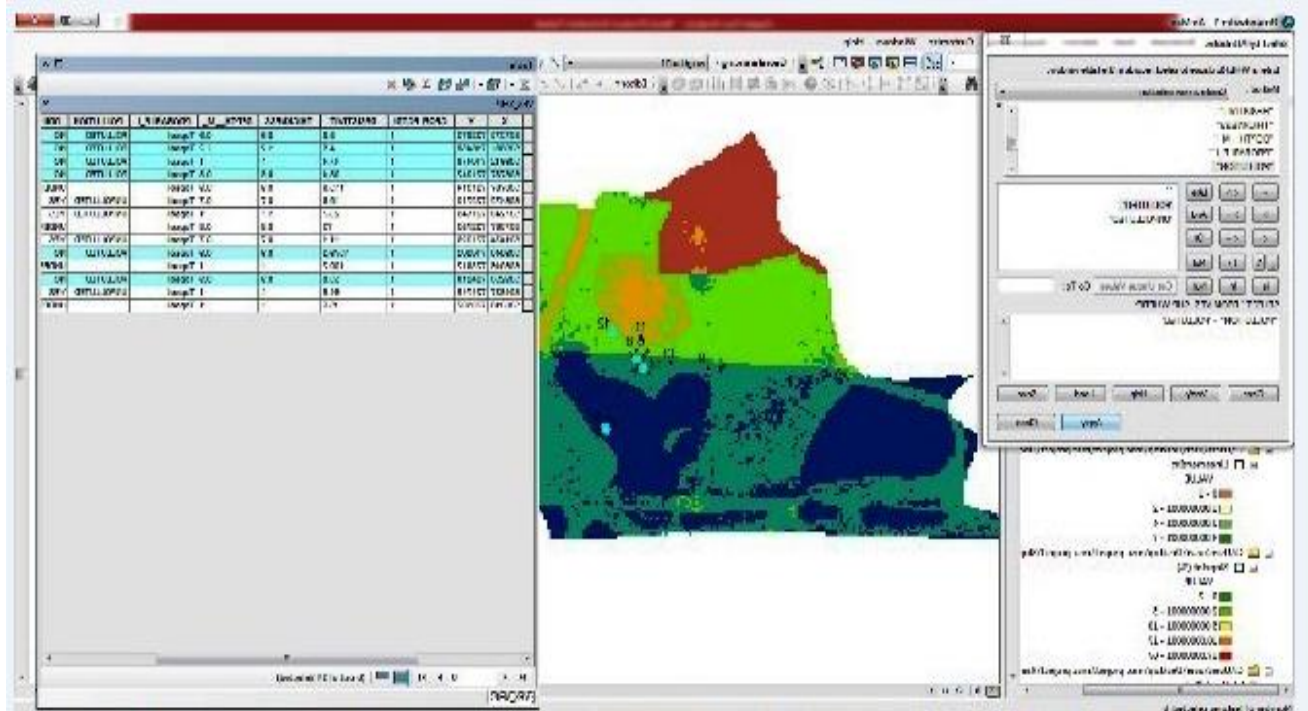

Figure 12: Overlay of ajao estate polluted point on potential ground

\section{- Query three:}

"DRILLABLE"='YES'. This shows areas that are drillable within Ajao estate. These areas according to VES result contain water that are beneficial. VES location 6, 7, 9, and 13 are found in this category. Relating the VES point to the groundwater map; as shown in Figures 13 and 14. It was discovered that they all fall into high potentiality category.

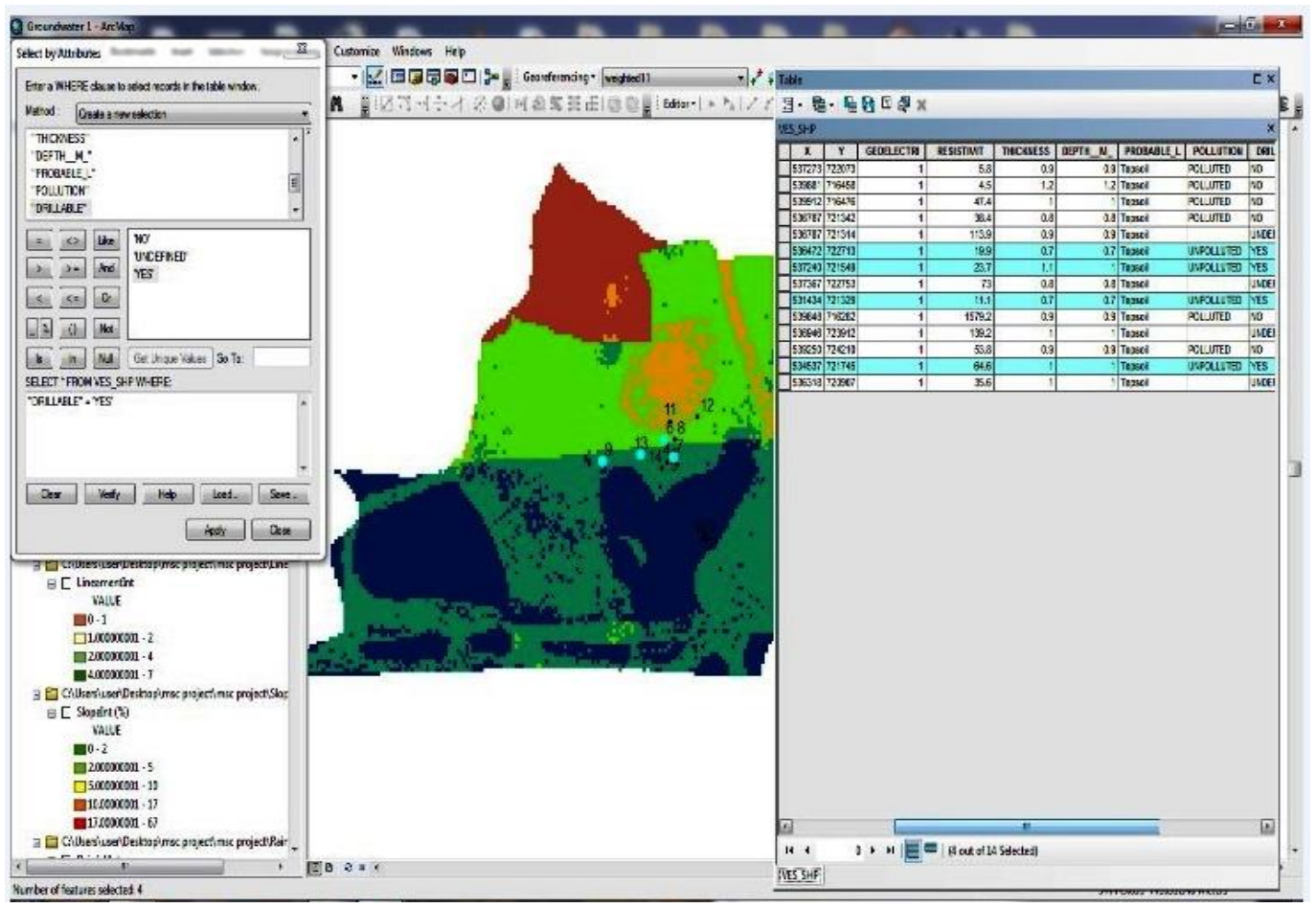

Figure 13: Drillable points or station 


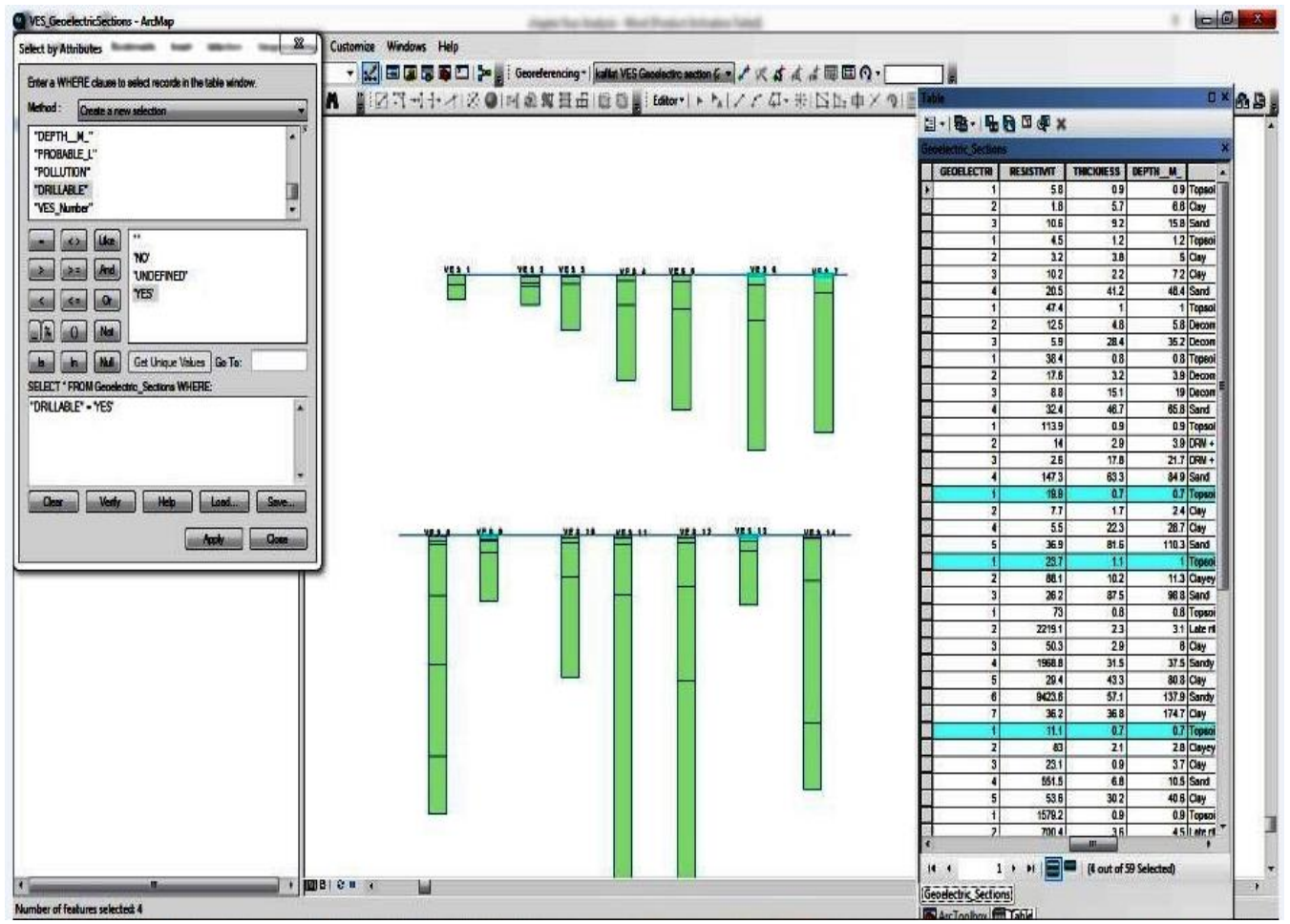

Figure 14: Geo-electric display of drillable points

\section{- Query four :}

"POLLUTION"= 'Polluted' OR "POLLUTION"= 'Unpolluted'. This entails areas that contain groundwater. VES location 1, 3, 5, 7, 9, 12 and 13 are found in this category. Figure 15 shows the VES locations with groundwater. The highlighted VES Locations are the ones with groundwater according to the VES data presented in the database.

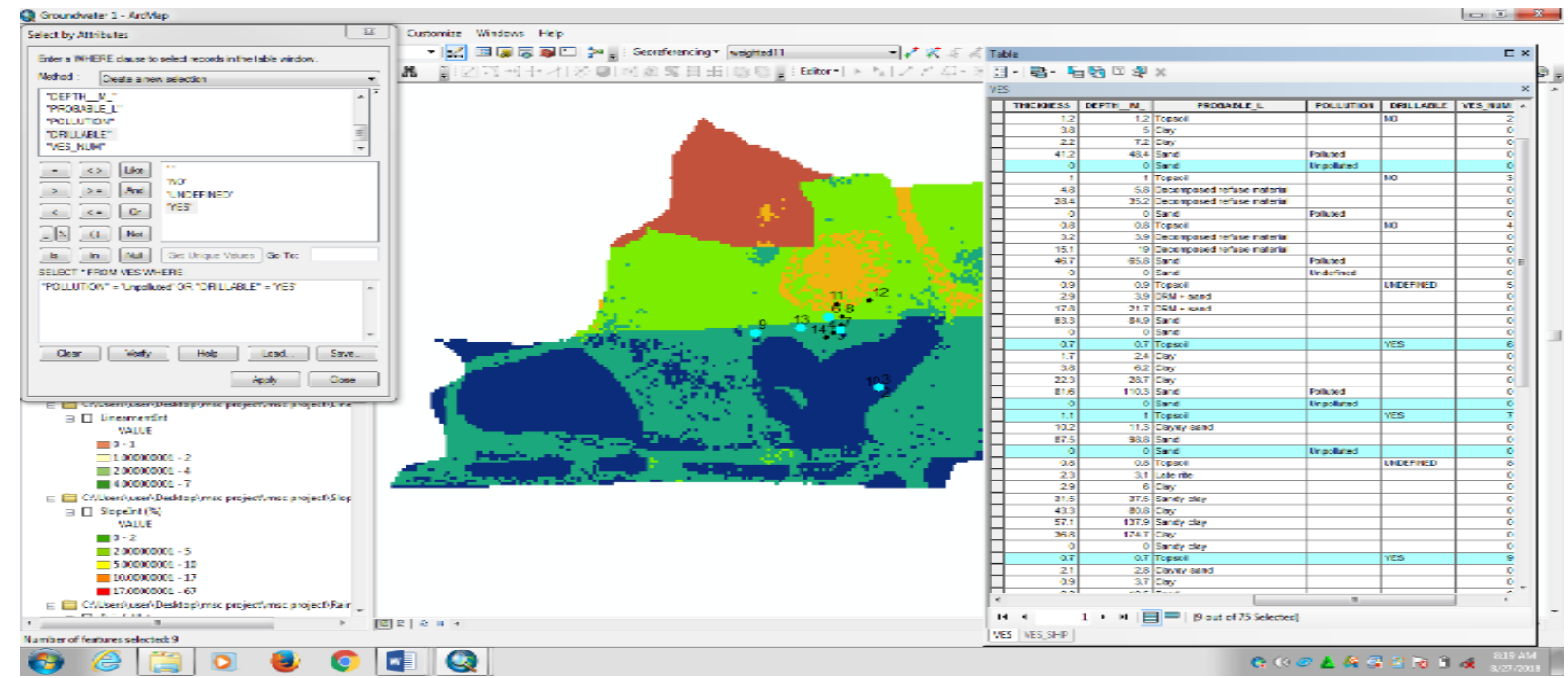

Figure 15: VES locations with groundwater

\section{- Query five:}

"POLLUTION" = 'Unpolluted' OR "DRILLABLE" = 'YES'. This entails area that contain clean water and are drillable within Ajao estate. This includes VES location 2, 6, 7, 9 and 13. Also, we found out that these VES station falls within very high, high and moderate potential of groundwater map. This has shown that the potentiality of groundwater map obtained is high as shown in Figure 16. 


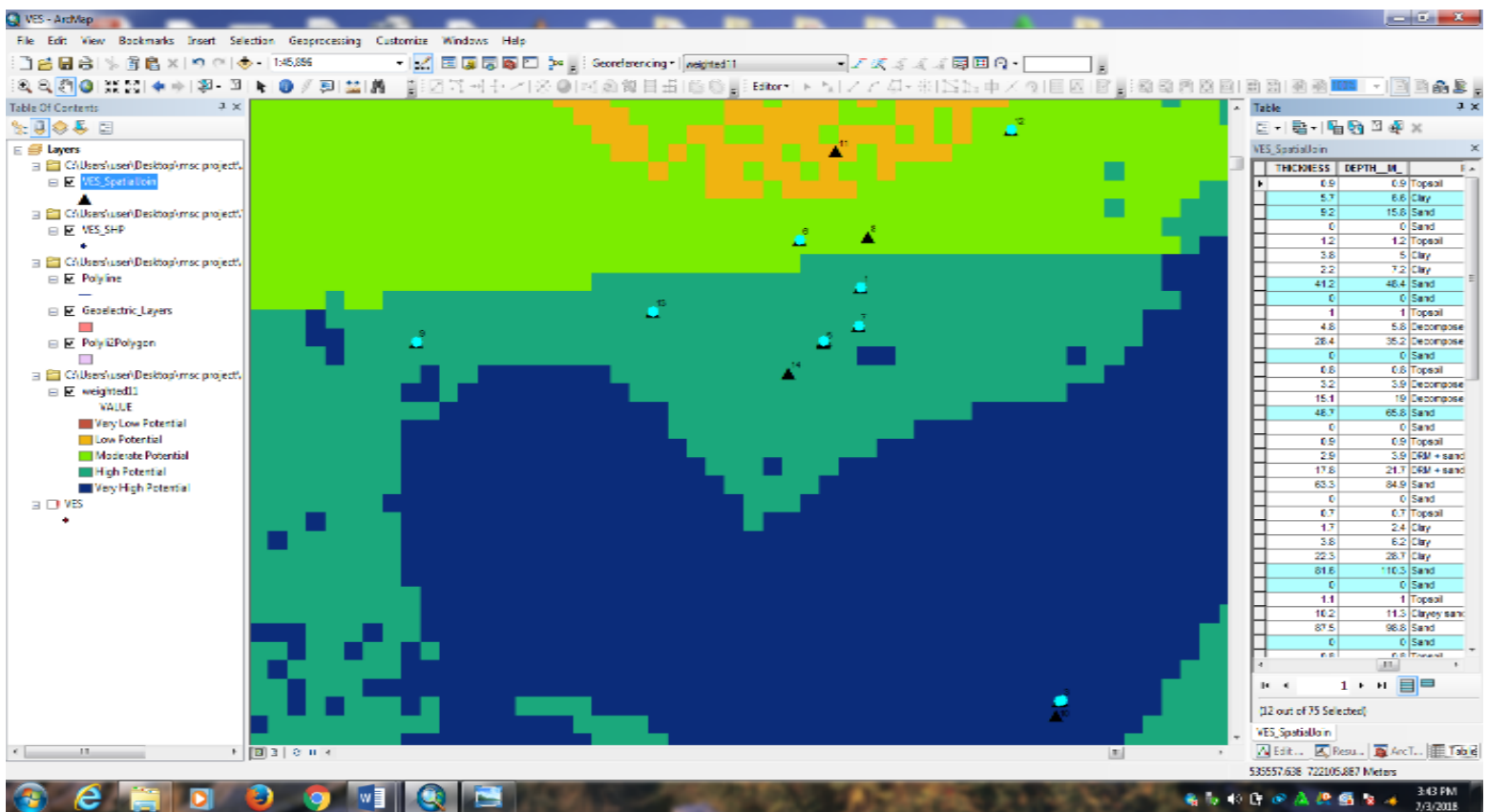

Figure 16: VES station that contain unpolluted clean water and are drillable

\section{- Query six:}

This was done to check the reason why some VES station was not selected within Ajao estate. We found out that it's because of the presence of buildings as shown in Figure 17.

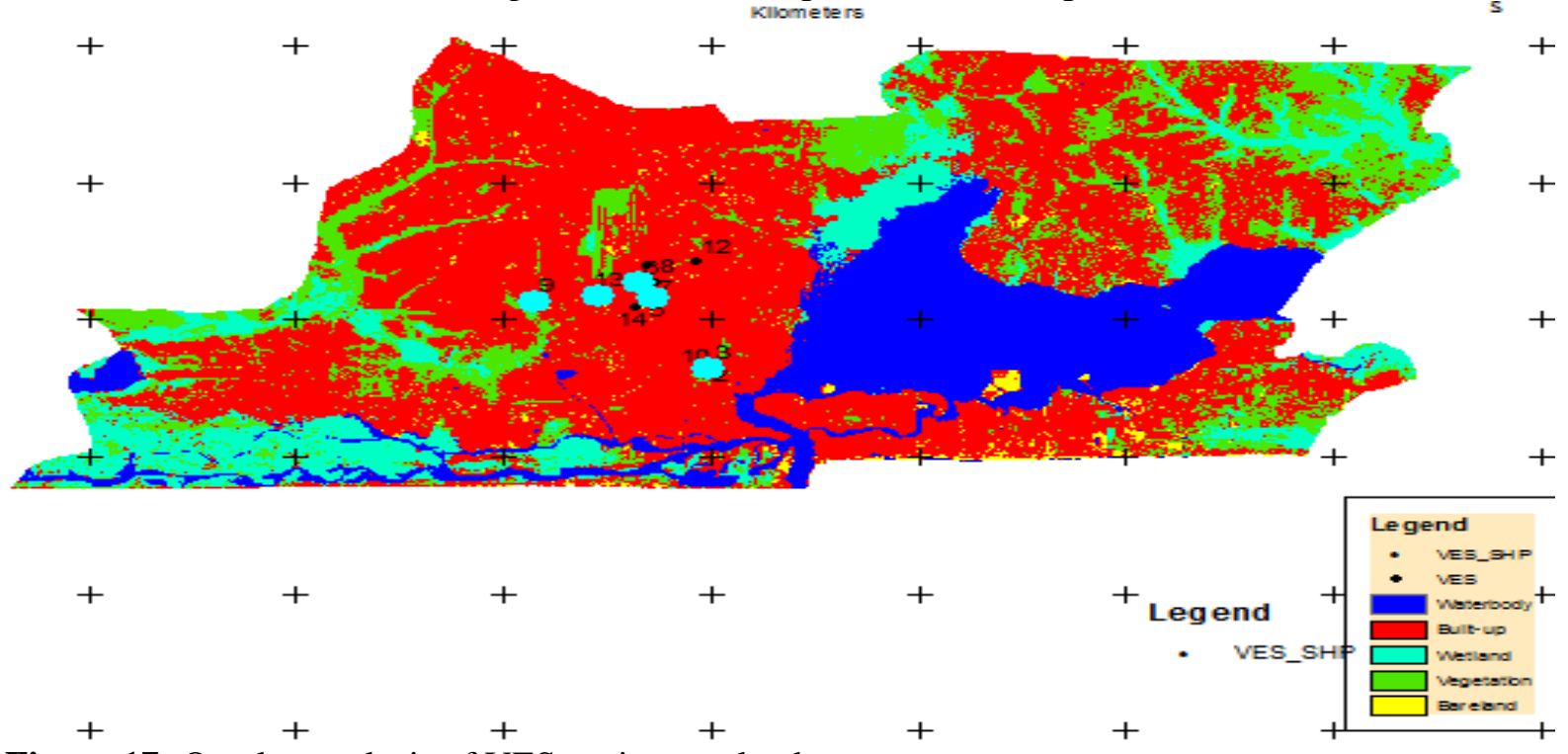

Figure 17: Overlay analysis of VES stations on land use map

\subsection{Conclusion}

It has been found that $23 \%$ of the total area comes under very high, $40 \%$ high, $28 \%$ moderate, $3 \%$ low and $6 \%$ of the total area falls under very low groundwater potential zone. Major portions of the study area has "high" as well as "moderate" prospect while a few scattered areas have "low" prospect. The very high potential areas are mainly concentrated along the River Alluvium while the "very low" prospect are majorly where there is sand and clay. The best groundwater potential zone is concentrated in the southern part of the study area due to the presence of fractures, swamp soils which have high infiltration ability as well as presence of waterbody which is chiefly accountable for the groundwater recharge in any area. Thus, the study reveals that; the integration of the thematic maps gives first-hand information to local authorities and planners about the areas suitable for groundwater exploration. Application of RS, GIS and Hydrogeophysics for the delineation of the groundwater potential zones in this study have proved to be efficient in terms of minimizing cost, time and labour. The study needs to be replicated in the areas with significant need of water for irrigation and drinking purpose. This map should be made available to serve as a base map before allocating lands for 
residential. This would prevent constructing buildings on areas that are viable. Remaining aspects of ground water occurrence, movement and utilization like ground water table condition and water requirement of various locations may be considered for future studies. Similar VES of the entire study area should be done for proper and precise check.

\section{References}

Foster, S.S.D. and Chilton, P.J. (1993). Groundwater Systems in the Humid Tropics. In: UNESCOIHP Humid Tropics Book. Cambridge University Press.

Gronwall, J.T., Mullenga, M. and McGranaham, G. (2010). Groundwater, Self-Supply and Poor Urban Dwellers: A Review with Case Studies of Bangalore and Lusaka. Human Settlements Programme, International Institute for Environment and Development (IIED), London.

Hill, M.B. and Webb, J.E. (1987). The Ecology of Lagos Lagoon II. The Topology and Physical features of Lagos Harbor and Lagos Lagoon. Phil. Trans. B. 241, pp. 319-333.

Jha, M.K., Chowdhury, A., Chowdary, V.M. and Peiffer, S. (2007). Groundwater management and development by integrated Remote Sensing and GIS: Prospects and constraints. Water Resources Management, 21, pp. 427-467.

Jones and Hockey (1964). Geology of South coast; Nigeria Geological Survey of Nigeria Bulletin No. 31, Geological Survey of Nigeria, Kaduna.

Khan, M.A. and Moharana, P.C. (2002). Use of Remote Sensing and Geographical Information System in the Delineation and Characterization of Groundwater Prospect Zones. Jour. India. Soc. Rem. Sen, 30(3), pp. 131-141.

Krishnamurthy, J., Kumar, N.V., Jayaraman, V., and Manivel, M., (1996). An approach to demarcate Groundwater potential zones through remote sensing and a geographic information system. Int. J. Remote Sensing, 17, pp. 1867-1885.

Longe, E.O., Malomo, S. and Oloruniwo, M.A. (1987). Hydrogeology of Lagos Metropolis. Journal of Africa earth Sciences, 1987, pp. 163-174.

ObiReddy, G.P., Mouli, K.C., Srivastav, S.K., Srinivas, C.V. and Maji, A.K. (2000). Evaluation of Groundwater Potential Zones using Remote Sensing Data - A Case Study of Gaimukh watershed, Bhandara District, Maharashtra. Jour. India. Soc. Rem. Sen, 28(1), pp. 19-32.

Ogunba, A. (2016). Sustainable groundwater management in Lagos, Nigeria: the regulatory framework (Doctoral dissertation, Université d'Ottawa/University of Ottawa).

Sander, P., Chesley, M.M. and Minor, T.B., (1996). Groundwater assessment using Remote Sensing and GIS in a rural Groundwater Project in Ghana: Lessons learned. Hydrogeology Journal, 4, pp. 4049.

Sankar, K. (2002). Evaluation of Groundwater potential zones using RS data in upper Vaigai River basin, Tamil Nadu. India. Journal of the Indian Society of Remote Sensing, 30, pp. 119-128.

Saraf, A.K. and Choudhury, P.R. (1998). Integrated Remote Sensing and GIS for Groundwater Exploration and Identification of artificial recharge sites. Intl. J. Rem. Sen, 19(10), pp. 1825 - 1841.

Shahid, S., Nath, S. and Roy, J. (2000). Groundwater potential modelling in a soft rock area using a GIS. International Journal of Remote Sensing, 21(9), pp. 1919-1924.

Soladoye, O. and Ajibade, L. T. (2014). A Groundwater Quality Study of Lagos State, Nigeria. International Journal of Applied Science and Technology l, 4(4). 
Solomon, S. (2003). Remote Sensing and GIS: applications for groundwater potential assessment in Eritrea (Doctoral dissertation, Byggvetenskap). 